Radical Vision 
This page intentionally left blank 


\section{Radical Vision}

A Biography of Lorraine Hansberry

Soyica Diggs Colbert 
Published with assistance from the foundation established in memory of Philip Hamilton McMillan of the Class of I894, Yale College.

Copyright (C) 2021 by Soyica Diggs Colbert.

All rights reserved.

This book may not be reproduced, in whole or in part, including

illustrations, in any form (beyond that copying permitted by Sections 107 and IO8 of the U.S. Copyright Law and except by reviewers for the public press), without written permission from the publishers.

Yale University Press books may be purchased in quantity for educational, business, or promotional use. For information, please e-mail sales.press@yale.edu (U.S. office) or sales@yaleup.co.uk (U.K. office).

Set in Adobe Garamond type by IDS Infotech Ltd. Chandigarh, India.

Printed in the United States of America.

ISBN 978-0-300-24570 7 (alk. paper)

Library of Congress Control Number: 2020943772

A catalogue record for this book is available from the British Library.

This paper meets the requirements of ANSI/NISO Z39.48-1992 (Permanence of Paper). 
To Rodger 
This page intentionally left blank 